\title{
EFFECT OF GROWTH REGULATOR ANALOGUES PYRIPROXFEN, HYDROPRENE AND THEIR COMBINATIONS WITH DELTAMETHRIN ON REPRODUCTION OF BOOPHILUS ANNULATS
}

\author{
WALEED M. ARAFA ${ }^{1}$ and HESHAM A. MAHRAN ${ }^{2}$ \\ ${ }^{1}$ Parasitology Department, Faculty of Veterinary Medicine, Beni-Suef University, Egypt. \\ ${ }^{2}$ Department of Hygiene, Management and Zoonoses, Faculty of Veterinary Medicine, Beni-Suef University, Egypt.
}

Received: 21 June 2016; Accepted: 21 July 2016

\begin{abstract}
Effect of growth regulator analogues, pyriproxfen, hydroprene and their combinations with deltamethrin on Boophilus annulatus was investigated. Fully engorged female $B$. annulatus ticks were collected from naturally infected cattle. The collected ticks were divided into 6 groups of 5 replicates; control untreated, pyriproxfen, pyriproxfen - deltamethrin, hydroprene, hydroprene - deltamethrin, and deltamethrin. Insect growth regulators (IGRs) and deltamethrin were dissolved in DMSO 10\% then diluted with distilled water before application. Adult immersion test for the different compounds was applied on engorged female ticks. Reduction of egg mass per female, reproductive index (RI), reproductive efficiency index (REI), and dead tick \% in the different groups were estimated. Consequently, the deposited eggs of the different groups were incubated to record the hatching $\%$. Furthermore, egg immersion test of untreated ticks was conducted in the different preparations. Both of pyriproxfen and hydroprene groups had no lethal effect to adult female ticks. Meanwhile, hydroprene and pyriproxfen treated groups showed significant reduction in the egg mass $(P \leq 0.0001)$ with the control untreated. The highest reduction of egg deposition was estimated in hydroprene - deltamethrin combination groups. There was non-significant difference in hatchability of deposited egg mass of the different groups. Furthermore, with egg immersion test, there was non-significant difference in hatchability of treated eggs including deltamehrin in a comparison with untreated eggs. Hatched larvae in different treatments did not show any abnormal changes. Both of pyriproxfen and hydroprene groups had no lethal effect on adult female ticks in a comparison with deltamethrin groups and deltamethrin-GRAs combination.
\end{abstract}

Key words: Growth regulator, Analogues pyriproxfen, Hydroprene, Boophilus annulats

\section{INTRODUCTION}

Ticks are the most predominant ectoparasites of cattle all over the world specially tropical and subtropical area. In Egypt, $B$. annulatus is the most common tick species infesting cattle (El Kammah, 2001). Blood feeding habits of tick and its activity as vectors of diseases of economic importance represent threats for the livestock industry in Africa (FAO, 1984). Tick-borne diseases (TBD), mainly babesiosis and anaplasmosis present serious constraints to productivity of particularly exotic cattle and their crosses. Cattle breeders and farmers based extensively on chemical acaricides for control the ticks. Thus there is huge demand for acaricides in Egypt. Incorrect dilution, application methods and extensive acaricide pressure are amongst factors that accelerate development of acaricide resistance (Aguilar- Tipacamu et al., 2011 and Abbas et al.,

Corresponding author: Dr. WALEED M. ARAFA

E-mail address: wmarafa@yahoo.com

Present address: Parasitology Department, Faculty of Veterinary Medicine, Beni-Suef University, Egypt.
2014). Synthetic pyrethroid (SP) resistance in $R$. (B.) microplus, a species close to $R$. (B.) annulatus, from India, Mexico, Brazil, North America and Australia was recorded (Nolan et al., 1989; Miller et al., 2007; Mendes et al., 2011; Rodriguez-Vivas et al., 2012 and Sharma et al., 2012).

Smart approach to insect pest control is the use of substances that badly affect insect reproduction, growth and development. These substances are classified as insect hormone mimics (Juvenile hormone) or insect growth regulators (IGRs) (Invest and Lucas, 2008). These analogs act by contact or ingestion, and end up in eggs via adult that came into contact with the active ingredients or directly through the cuticle of the eggs (Beugnet and Franc, 2012). Interestingly, IGRs generally control insects either through regulation of metamorphosis or interference with reproduction (Riddiford and Truman, 1978). Extracts of Meliaazedarach (IGR) inhibit egg production of immersed B. microplus ticks (Borges et al., 2003). These analogs are either used in the environment, in the form of sprays or diffusers often combined with an insecticide, or applied directly on animals (Beugnet and Franc, 2012). Juvenile 
hormone analogs include methoprene and Smethoprene (active isomer), pyriproxyfen (Jacobs et al., 1996 and Stanneck et al., 2002). In most cases, these analogs are used in animals in combination with an insecticide/ acaricide such as fipronil, permethrin, dinotefuran, or imidacloprid (Beugnet and Franc, 2012). Combination of synthetic pyrithroides (SPs) with the GRA is a way to overcome the acaricides resistance. A formulation combining dinotefuran, permethrin and pyriproxyfen (Vectra $3 \mathrm{D}^{\mathrm{TM}}$ ) was registered in the USA in 2007 and is indicated for the prevention and the treatment of sandfly, fleas, ticks and mosquitoes in dogs (Franc et al., 2012 and Liénard et al., 2013). Juvenile hormone analogs (JHAs) induce elevated levels of juvenile hormone, which interferes with reproduction in the arthropod target (Goodman et al., 2012). There is one licensed product containing hydroprene available for bed bug treatments (Hydroprene Zoecon Ltd., Schaumburg, Illinois, USA (Potter et al., 2010). The combination of several products (acaricides, insecticides and insect growth regulators) is available and safe for the integrated control of ectoparasites on domestic dogs. Insects developing resistance to one insecticide should theoretically still be killed by the second insecticide and thus prevent the resistance genes from passing to the next generation (Horak et al., 2012 and Ohashi et al., 2012).

The present study aimed to compare influence of pyriproxfen, hydroprene and their combinations with deltamethrin on reproductive capacity of $B$. annulatus tick.

\section{MATERIALS AND METHODS}

\section{Ticks collection}

Fully engorged female $B$. annulatus ticks were collected according Rodriguez-vivas et al. (2012) directly from naturally infested animals none of which had received tick treatments for at least 30 days. The ticks were placed in identified plastic bottles free of acaricide residues with lids containing small holes, and transported to the parasitology laboratory, Faculty of Veterinary medicine in BeniSuef University.

\section{Tick preparation}

The freshly collected ticks were divided into 6 groups of 10 ticks of five replicates in each trail in clean labeled petri dishes. Ticks were weighted and divided to be equal in the different groups. In the laboratory, all females were separated, carefully washed, and then dried on absorbent paper. Engorged females weighing not less than $140 \mathrm{mg}$, with no signs of injury, were used in the study. Selected ticks were admitted to the adult immersion test as soon as possible post collection (not more than 24 hours).

\section{IGR Preparation.}

Commercial solution of Martin's IGR $\AA$ (pyriproxfen $1.3 \%$ ) was diluted with DMSO $10 \%$ to achieve the complete solubility of the product. About $200 \mu \mathrm{l}$ of pyriproxfen 1.3 completed to $1 \mathrm{ml}$ with DMSO $10 \%$. Subsequently $1 \mathrm{ml}$ Pyriproxfen / DMSO compound completed up to $10 \mathrm{ml}$ with DW in $15 \mathrm{ml}$ labelled plastic tube to obtain a $0.26 \mathrm{mg} / \mathrm{ml}$ pyriproxfen concentration (2.5 $\mathrm{X}$ the recommended dose). Similarly, $200 \mu \mathrm{l}$ of Gentrol ® IGR concentrate (9\% Hydroprene) was completed to $1 \mathrm{ml}$ with DMSO $10 \%$. Later, $1 \mathrm{ml}$ hydroprene / DMSO combination was completed to $10 \mathrm{ml}$ with DW to form a $1.8 \mathrm{mg} /$ $\mathrm{ml}$ hydroprene concentration $(2.5 \mathrm{X}$ the recommended dose). Deltamethrin $5 \%$ was diluted with DMSO $(20 \mu 1$ deltamethrin $5 \%+980 \mu \mathrm{l}$ DW). Deltamethrin / DMSO combination completed to 10 $\mathrm{ml} \mathrm{DW}$ to obtain $1 \mathrm{mg} / 10 \mathrm{ml}$. For pyriproxfen / deltamethrin combination, about $200 \mu 1$ pyriproxfen plus $20 \mu \mathrm{l}$ deltamethrin were completed to $1 \mathrm{ml}$ with DMSO. Then the product was completed to $10 \mathrm{ml}$ with DW. Hydroprene / deltamethrin combination was performed similar to the last one. Control tubes were composed of $200 \mu \mathrm{LMSO}$ and completed to $10 \mathrm{ml} \mathrm{DW}$.

\section{Adult Immersion Test (AIT)}

AIT was performed as described by Sharma et al. (2012) with minor modifications. The ticks were weighed and assigned to groups. The different groups of ticks were immersed in $10 \mathrm{ml}$ of the different treatments by placing them directly into Petri dish and stirred with glass rod before and after adding ticks. After $2 \mathrm{~min}$, the acaricide was poured off through a sieve and the ticks were transferred to the filter paper for drying and kept separately in glass tubes and sealed with cotton. For each concentration five replicates were maintained. Simultaneously, the ticks in the control group were treated with DMSO. The treated ticks were kept in BOD incubator at a temperature of $27 \pm 2{ }^{\circ} \mathrm{C}$ and relative humidity of 80 $\pm 10 \%$ for oviposition.

The eggs laid by the treated ticks were collected at one week post treatment with brush, weighed. Average of tick eggs per female was calculated. Collected eggs were transferred to labeled glass tubes (About $140 \mathrm{mg} /$ tube) and observed at the same conditions of incubation for up to 30 days for visual estimation of hatching.

Reproductive index (RI), reproductive efficiency index (REI), and the percentage inhibition of oviposition (IO), hatching \%, and hatching inhibition were calculated (Goncsalves et al., 2007 and Drummond et al., 1973) as follows:

$\boldsymbol{R I}=$ Average weight of eggs laid mg / Average weight of live ticks mg 
$\boldsymbol{R E I}=$ egg mass weight $\times \%$ egg hatching/engorged female weight $\times 20.000^{*}$

Where * shows the constant that indicates the number of eggs present in $1 \mathrm{~g}$.

Percentage inhibition of oviposition (IO \%)

$=$

RI (control group) - RI (treated group) / RI (control group) $\times 100$.

Percentage inhibition of hatching (IH\%) = $[($ Hatching $\%$ control - Hatching $\%$ treated $) /$ Hatching $\%$ control $\times 100]$.

$\mathrm{HC}$ and $\mathrm{HT}$ are the hatching of the control and treated groups.

\section{Dead tick \%}

The mortality was observed on day 14 post treatment (PT). The ticks which did not oviposit even after 14 days were considered as dead (Sharma et al., 2012).

Dead tick $\%=$ Number of dead tick in treated groups - Number of dead tick in control groups / Total number of treated tick $\times 100$

\section{Egg Immersion Test (EIT)}

Egg immersion test was conducted according to the method of Ribeiro et al. (2008) with minor modifications. Approximately $100 \mathrm{mg} \mathrm{B}$. annulatus embryonated eggs were weighted in a filter paper and immersed for $2 \mathrm{~min}$ in $10 \mathrm{ml}$ of the test solutions. Subsequently, the solutions were decanted and after evaporation of the solvent the filter papers were let up to 30 minutes till complete dryness. After that, treated eggs were transferred into clean labeled tubes covered with a cotton. Eggs were incubated at $28 \pm 1{ }^{\circ} \mathrm{C}$ and $80 \pm 10 \%$ relative humidity for $2-4$ weeks, until hatching was completed. Water was used as control and each treatment contained 5 replicates. The following parameters were compared:

(a) Hatching $(\%)=$ [The number of hatched larvae divided by the total number of incubated eggs $\times 100$ ] (b) Percentage inhibition of hatching (IH \%) = [(Hatching \% control - Hatching \% treated) / Hatching $\%$ control $\times 100]$.

\section{Statistics}

Data were analyzed statistically using Statistical Package for Social Science (SPSS for Windows (IBM), version 22, Chicago, USA) to determine if variables differed between treatments. Data were analyzed using ANOVA tests and subsequent Duncan's multiple range test to determine the differences between means. Results are expressed as means \pm SD. Probability values of less than 0.05 ( $P<$ 0.05 ) were considered significant.

\section{RESULTS}

\section{Eggs mass per female tick and reproductive index} Egg mass per female ticks was $53.6 \pm 3.2$ in control untreated, and reduced significantly in pyriproxfen, pyriproxfen deltamethrin, hydroprene, hydroprene deltamethrin, and deltamethrin groups $(P \leq 0.0001)$. The lowest egg mass per females was recorded in deltamethrin GRAs combinations. Inhibition of oviposition \% was $1.15 \pm 2.19$, in control untreated, and increased significantly in the different treated groups $(P \leq 0.0001)$. Comparing the egg mass to the female tick weights was decreased significantly in the different groups with the control $(P \leq 0.0001)$. The RI was $0.36 \pm .008$ in control untreated, was decreased significantly in the different groups with the control $(P \leq 0.0001)$. The lowest RI was in deltamethrin and GRA deltamethrin combination groups (Fig.1, 2, 3, table 1).

\section{Hatching inhibition\%}

There was non-significant difference in hatching $\%$ of incubated eggs including deltamethrin groups with control untreated $(91.6 \pm 2.8 \%)$. Hatched larvae in all groups had not any apparent morphological abnormalities. The reproductive efficiency index (REI) of the all treated groups was varied significantly $(P \leq 0.0001)$ with the control.

\section{Percentage of dead tick}

With the adult immersion test, neither pyriproxfen nor hydroprene has acricidal effect in a comparison with the control untreated. GRA alone didn't show any lethal effect on the adult ticks. On the contrary, deltamethrin, and GRA deltamethrin combination showed significant deaths of immersed ticks. Dead \% was $83.3 \pm 5.7,86.6 \pm 5.7$, and $83.3 \pm 5.7$ in pyriproxfen deltamethrin, hydroprene deltamethrin and deltamethrin groups respectively (Fig 4).

\section{Egg hatching inhibition assay}

Immersed eggs in the different groups were able to hatch and produced active larvae without apparent abnormalities. There were non-significant differences in hatching inhibition $\%$ of the immersed ticks in the different groups in a comparison with control untreated $(20 \pm 17.3 \%)$. 

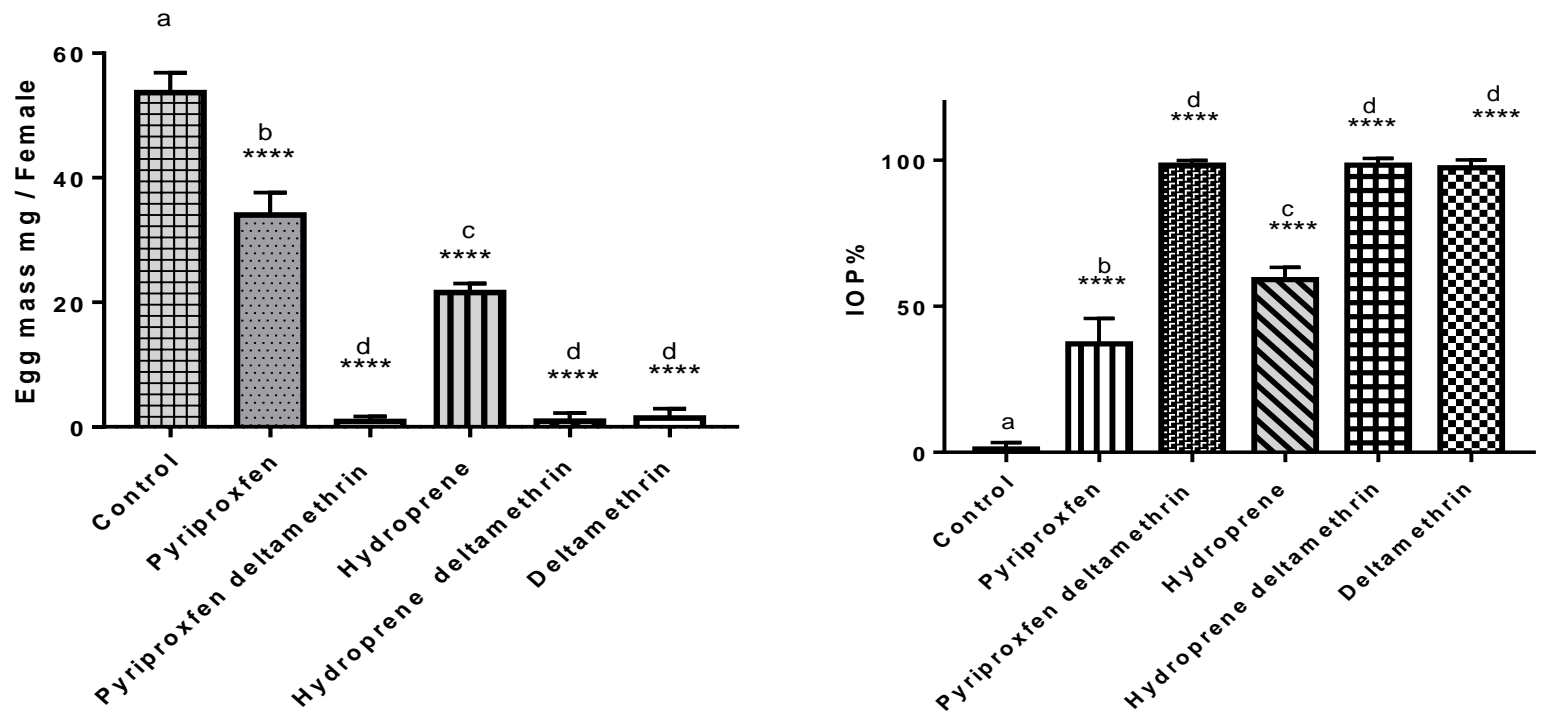

Fig. 1: Egg mass (mg) per female ticks in the different groups. Significant differences between control and treated groups are indicated by $* * * *$ $(P \leq 0.0001)$.

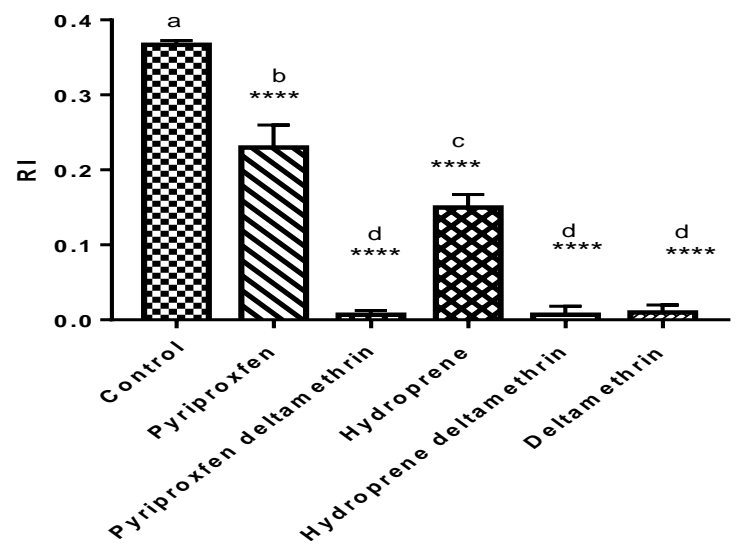

Fig. 3: Reproductive index of female tick in the different groups. Significant differences between control and treated groups are indicated by $* * * *$ $(P \leq 0.0001)$.

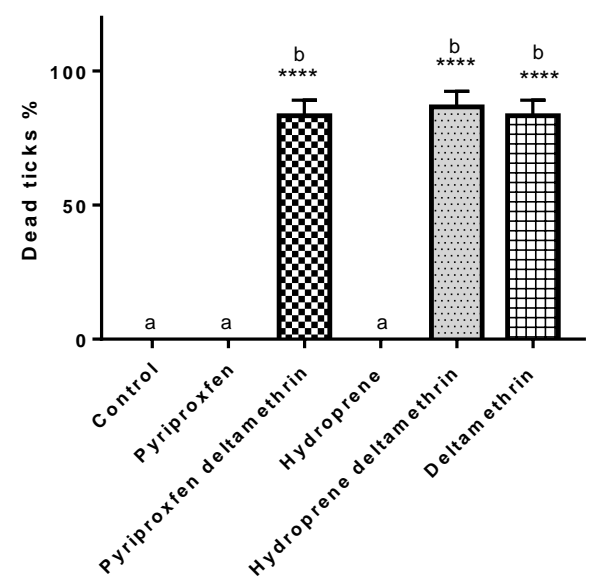

Fig. 2: Inhibition of oviposition $\%$ in the different groups. Significant differences between control and treated groups are indicated by $* * * *$ $(P \leq 0.0001)$.

Fig. 4: Percentage of dead ticks in the different groups. Significant differences between control and treated groups are indicated by $* * * *(P \leq 0.0001)$. 
Table 1: Reproductive efficacy and dead $\%$ of different tick groups

\begin{tabular}{|c|c|c|c|c|c|c|c|c|c|c|}
\hline Group & $\begin{array}{c}\text { Average } \\
\text { of female } \\
\text { weight } \\
(\mathrm{mg}) \pm \text { SD }\end{array}$ & $\begin{array}{c}\text { Average } \\
\text { Egg Mass } \\
\text { (mg) / } \\
\text { female } \pm \\
\text { SD }\end{array}$ & $\begin{array}{c}\text { Reduction } \\
\text { OVP \% } \\
\text { 土SD }\end{array}$ & $\begin{array}{l}\text { IOP } \\
\pm \text { SD }\end{array}$ & $\begin{array}{c}\text { Hatching } \\
\%\end{array}$ & $\begin{array}{c}\text { Hatching } \\
\text { inhibition } \\
\%\end{array}$ & $\begin{array}{l}\text { Reproductive } \\
\text { index } \pm \text { SD }\end{array}$ & $\begin{array}{c}\text { Egg } \\
\text { hatching } \\
\text { assay } \\
\text { inhibition }\end{array}$ & $\begin{array}{c}\text { REI } \pm \\
\text { SD }\end{array}$ & $\begin{array}{c}\text { Dead } \\
\text { tick } \\
\% \pm \text { SD }\end{array}$ \\
\hline Control & $\begin{array}{c}146.6^{\mathrm{a}} \pm \\
5.7\end{array}$ & $\begin{array}{c}53.6^{\mathrm{a}} \pm \\
3.2\end{array}$ & $\begin{array}{l}0.00^{\mathrm{a}} \\
\pm 0.00\end{array}$ & $\begin{array}{l}1.15 \pm \\
2.19^{a}\end{array}$ & $\begin{array}{l}91.66 \\
\pm 2.88\end{array}$ & $\begin{array}{r}8.33 \\
\pm 2.8\end{array}$ & $\begin{array}{l}0.36^{\mathrm{a}} \\
\pm .008\end{array}$ & $\begin{array}{c}20.0 \\
\pm 17.3\end{array}$ & $\begin{array}{r}670.5^{\mathrm{a}} \\
\pm 26.93\end{array}$ & $\begin{array}{l}0.0^{\mathrm{a}} \\
\pm 0.0\end{array}$ \\
\hline Pyriproxfen & $\begin{array}{c}146.6^{\mathrm{a}} \pm \\
5.7\end{array}$ & $\begin{array}{c}34.0^{b} \pm \\
3.6\end{array}$ & $\begin{array}{l}36.56^{b} \\
\pm 6.72\end{array}$ & $\begin{array}{c}37.15 \pm \\
8^{6.68}\end{array}$ & $\begin{array}{l}92.66 \\
\pm 2.51\end{array}$ & $\begin{array}{r}7.33 \\
\pm 2.5\end{array}$ & $\begin{array}{c}0.20^{\mathrm{b}} \\
\pm 0.032\end{array}$ & $\begin{array}{c}15.6 \\
\pm 12.5\end{array}$ & $\begin{array}{c}430.52^{b} \\
\pm 56\end{array}$ & $\begin{array}{l}0.0^{\mathrm{a}} \\
\pm \mathbf{0 . 0}\end{array}$ \\
\hline $\begin{array}{l}\text { Pyriproxfen } \\
\text { deltamethrin }\end{array}$ & $\begin{array}{c}146.6^{\mathrm{a}} \pm \\
5.7\end{array}$ & $\begin{array}{c}0.8^{\mathrm{d}} \pm \\
.80\end{array}$ & $\begin{array}{l}98.38^{d} \\
\pm 1.50\end{array}$ & $\begin{array}{l}98.4 \pm \\
1.55^{d}\end{array}$ & $\begin{array}{l}91.66 \\
\pm 2.88\end{array}$ & $\begin{array}{r}8.33 \\
\pm 2.8\end{array}$ & $\begin{array}{l}0.006^{\mathrm{c}} \\
\pm 0.005\end{array}$ & $\begin{array}{c}16.6 \\
\pm 11.5\end{array}$ & $\begin{array}{l}10.85^{d} \\
\pm 10.33\end{array}$ & $\begin{array}{l}83.3^{b} \\
\pm 5.7\end{array}$ \\
\hline Hydroprene & $\begin{array}{c}143.3^{\mathrm{a}} \pm \\
5.7\end{array}$ & $\begin{array}{c}21.6^{c} \pm \\
1.4\end{array}$ & $\begin{array}{l}59.70^{\mathrm{c}} \\
\pm 2.69\end{array}$ & $\begin{array}{c}59.16 \pm \\
4.23^{\mathrm{c}}\end{array}$ & $\begin{array}{l}91.66 \\
\pm 2.88\end{array}$ & $\begin{array}{c}8.3 \\
\pm 2.8\end{array}$ & $\begin{array}{l}0.151^{\mathrm{c}} \\
\pm 0.015\end{array}$ & $\begin{array}{c}18.3 \\
\pm 14.4\end{array}$ & $\begin{array}{r}277.2^{c} \\
\pm 32.36\end{array}$ & $\begin{array}{l}0.0^{\mathrm{a}} \\
\pm \mathbf{0 . 0}\end{array}$ \\
\hline $\begin{array}{l}\text { Hydroprene } \\
\text { deltamethrin }\end{array}$ & $\begin{array}{c}152.3^{\mathrm{a}} \pm \\
4.0\end{array}$ & $\begin{array}{c}0.9^{\mathrm{d}} \pm \\
1.2\end{array}$ & $\begin{array}{l}98.25^{\mathrm{d}} \\
\pm 2.37\end{array}$ & $\begin{array}{c}98.32 \pm \\
2.29^{d}\end{array}$ & $\begin{array}{l}92.66 \\
\pm 2.51\end{array}$ & $\begin{array}{c}7.3 \\
\pm 2.5\end{array}$ & $\begin{array}{l}0.006^{\mathrm{c}} \\
\pm .008\end{array}$ & $\begin{array}{c}15.6 \\
\pm 12.5\end{array}$ & $\begin{array}{l}11.75^{d} \\
\pm 16.19\end{array}$ & $\begin{array}{l}86.6^{b} \\
\pm 5.7\end{array}$ \\
\hline Deltamethrin & $\begin{array}{c}146.6^{\mathrm{a}} \pm \\
5.7\end{array}$ & $\begin{array}{c}1.4^{\mathrm{d}} \pm \\
1.5\end{array}$ & $\begin{array}{l}97.38^{d} \\
\pm 2.81\end{array}$ & $\begin{array}{c}97.47 \pm \\
2.72^{d}\end{array}$ & $\begin{array}{l}92.66 \\
\pm 2.5\end{array}$ & $\begin{array}{c}7.3 \\
\pm 2.5\end{array}$ & $\begin{array}{c}0.009 \\
c_{ \pm .010}\end{array}$ & $\begin{array}{r}12.3 \\
\pm 6.8\end{array}$ & $\begin{array}{l}17.20^{d} \\
\pm 18.75\end{array}$ & $\begin{array}{l}83.3^{\mathrm{b}} \\
\pm 5.7\end{array}$ \\
\hline
\end{tabular}

Superscript of the same letter in cells of the same column is non-significant with the control. Superscript of different letters in cells of the same column is significant $(P \leq 0.0001)$

\section{DISCUSSION}

In fact, ticks are the chief ectoparasites of domesticated animals, and its risks as vectors of lethal pathogens are being considered by the animal breeders all over the world. In the current study, egg mass of treated ticks was reduced significantly $(P \leq$ $0.0001)$ in the different treated groups in a comparison with untreated control. The RI was significantly decreased $(P \leq 0.0001)$ in different treated groups in a comparison with the untreated. Pyriproxfen and hydroprene treated groups showed inhibition of oviposition (IOP) $(P \leq 0.0001)$. Meanwhile, combination of GRAs either pyriproxfen or hydroprene with deltamethrin and deltamethrin groups showed the highest IOP per female tick, 98.4 $\pm 1.55,98.32 \pm 2.29$, and $97.47 \pm 2.72$ respectively. Topical application of JHAs onto the mosquito abdomen has been reported to reduce fecundity (Patterson, 1974). Moreover, evidence suggests that tarsal contact with a pyriproxyfen-treated substrate induces reduction of fecundity in adult females of Aedes aegypti (Itoh et al., 1994). Moreover, Miler (1994) reported that exposure of a susceptible and a pyrethroid- resistant strain of Anopheles stephensi to a net treated with pyriproxyfen produced only a 33 and $55 \%$ reduction in the number of eggs, respectively. Furthermore, Ohashi et al. (2012) demonstrated that adult female Anopheles gambiae that came into contact with pyriproxyfen treated netting were sterilized or had reduced fecundity and shortened longevity.

It is of interest to clarify that, all treated GRAs groups and their combination with deltamethrin showed nonsignificant difference in hatchability of eggs laid by treated females and immersed eggs in a comparison with control untreated groups. Therefore, this study clarified that, GRAs pyriproxfen, and hydroprene have not effect on embryogenesis and hatchability. Meanwhile, reproductive efficiency index (REI) of the all treated groups was decreased significantly $(P \leq$ 0.0001 ) in treated groups in a comparison with the control. On the contrary, several studies were carried on different insects, and ticks showed that, GRAs inhibit metamorphosis and embryogenesis and hatching of several insects, and has no crossresistance to older class chemicals, including pyrethroids (Dhadialla et al., 1998; Roe et al., 2008; Dhadialla et al., 2010; Wijayaratne et al., 2012; Ginjupalli and Baldwin 2013 and Brar et al., 2015).

Concerning the acricidal activity, neither pyriproxfen nor hydroprene has acricidal effect. Therefore, GRAs alone didn't show any lethal effect on the adult ticks. Study showed that, pyriproxyfen did not kill adult insects, flies and ticks (Liénard et al., 2013). On the contrary, deltamethrin, GRAs deltamethrin combination showed significant deaths of immersed ticks. The treatment of dogs with permethrin- 
dinotefuran-pyriproxyfen formulation offer better protection from Aedes mosquito bites than formulations of lower or similar dosage of permethrin combined with imidacloprid or with permethrin alone (Franc et al., 2012). In similar trials performed with A. aegypti (Meyer et al., 2003 and Tiawsirisup et al., 2007), insecticide efficacy for $65 \%$ permethrin alone ranged from $84 \%$ to $90.9 \%$, meanwhile, permethrindinotefuran-pyriproxyfen combination provided an insecticide efficacy between $93 \%$ (day 28) and $100 \%$ (day 7).

It is worthy to clarify that, acaricidal activity of deltamethrin alone in the current study was $83.3 \pm$ 5.7. Consequently, the resistant (live) female ticks produced viable eggs and hatched to active larvae. The insect growth regulator (IGR) pyriproxyfen is a juvenile hormone analog (JHA) with extremely low toxicity to mammals (FAO, 2004). Combination of deltamethrin with GRA did not affect the acricidal activity but the point is that, it reduced the egg mass deposited by resistant females. A formulation combining dinotefuran, permethrin and pyriproxyfen (Vectra 3D) was registered in the USA in 2007 and is indicated for the prevention and treatment of fleas, ticks, flies and mosquitoes on dogs (Franc et al., 2012; Liénard et al., 2013).

\section{CONCLUSION}

GRAs pyriproxfen and hydroprene reduced the reproductive index of Boophilus annulatus significantly $(P \leq 0.0001)$ in a comparison with the control untreated. GRAs have not significant effect on hatchability of the deposited egg mass. Combination of GRAs with deltamethrin is a way to overcome the acaricide resistance of Boophilus annulatus, since deposited egg mass of the resistant tick will be reduced.

\section{COMPETING INTERESTS}

The authors declare that there are no competing interests.

\section{ACKNOWLEDGMENT}

Acknowledgments The authors express their gratitude for Prof. Shawky M Aboelhadid for his advice and consultations during the course of the study. We appreciate veterinarians who helped us to get ticks from the field.

\section{REFERENCES}

Abbas, R.Z.; Zaman, M.A.; Colwell, D.D.; Gilleard, $J$. and Iqbal, Z. (2014): Acaricide resistance in cattle ticks and approaches to its management: the state of play. Vet. Parasitol. 203:6-20.
Aguilar-Tipacamu, G.; Rosario-Cruz, R.; Miller, R.J.; Guerrero, F.D.; Rodriguez-Vivas, R.I. and Garcia-Vazquez, Z. (2011): Phenotype changes inherited by crossing pyrethroid susceptible and resistant genotypes from the cattle tick Riphicephalus (Boophilus) microplus. Exp Appl Acarol. 54: 301-311.

Beugnet, F. and Franc, M. (2012): Insecticide and acaricide molecules and/or combinations to prevent pet infestation by ectoparasites. Trends Parasitol 7: 267-279

Borges, L.M.F.; Ferri, P.H.; Silva, W.J.; Silva, W.C. and Silva, J.G. (2003): In vitro extracts of Melia Azedarach against the tick Boophilus microplus. Med. Vet. Entomol. 17, 228-231.

Brar, G.S.; Meyer, W. and Stelinski, L.L. (2015): Effects of methoprene, a juvenile hormone analog, on survival of various developmental stages, adult emergence, reproduction and behavior of Asian citrus psyllid, Diaphorina citri Kuwayama. Pest Manag Sci. 71: 16571665

Dhadialla, T.S.; Carlson, G.R. and Le, D.P. (1998): New insecticides with ecdysteroidal and juvenile hormone activity. Annu. Rev. Entomol. 43: 545-569.

Dhadialla, T.; Retnakaran, A. and Smagghe, G. (2010): Insect growth- and developmentdisrupting insecticides, in Insect Control: Biological and Synthetic Agents, ed. by Gilbert IL and Gill SS. Academic Press, London, pp. 121-181.

Drummond, R.O.; Ernest, S.E.; Trevino, J.L.; Gladney, W.J. and Graham, O.H. (1973): Boophilus annulatus and Boophilus microplus: laboratory tests for insecticides. J.Econ. Entomol. 66, 130-133.

El Kammah, K.M. (2001): Ticks and Parasitic mites (In Arabic), Part I, Ticks. El AhramPressQalyub, Egypt, pp: 211.

FAO, (1984): Ticks and tickborne disease control: a practical field manual. Vol. 1. Food and Agriculture Organization of the United Nations. 1984.

FAO, (2004): Resistance Management and Integrated Parasite Control in Ruminants-Guidelines, Module 1. Ticks: Acaricide Resistance: Diagnosis, Management and Prevention, Food and Agriculture Organization, Animal Production and Health Division, Rome, Italy.

Franc, M.; Genchi, C.; Bouhsira; E.; Warin, S.; Kaltsatos, V.; Baduel, L. and Genchib, M. (2012): Efficacy of dinotefuran, permethrin and pyriproxyfen combination spot-on against Aedes aegypti mosquitoes on dogs. Vet. Parasitol 189: 333-337.

Ginjupalli, G.K. and Baldwin, W.S. (2013): The timeand age-dependent effects of the juvenile hormone analog pesticide, pyriproxyfen on 
Daphnia magna reproduction. Chemosphere 92: 1260-1266.

Goodman, M.H.; Potter, M.F. and Haynes, KF. (2012): Effects of juvenile hormone analog formulations on development and reproduction in the bed bug Cimex lectularius (Hemiptera: Cimicidae). Pest Manag Sci 69: 240-244.

Gonc,alves, K.; Toigo, E.; Ascoli, B.; Von Poser, G. and Ribeiro, V.L.S. (2007): Effects of solvents and surfactant agents on the female and larvae of cattle tick Boophilus microplus," Parasitol Res, vol. 100, 1267-1270.

Horak, I.G.; Fourie, J.J. and Stanneck, D. (2012): Efficacy of slow-release collar formulations of imidacloprid/ flumethrin and deltamethrin and of spot-on formulations of fipronil/(s) methoprene, dinotefuran/ pyriproxyfen/permethrin and (s)methoprene/amitraz/ fipronil against Rhipicephalus sanguineus and Ctenocephalides felis felis on dogs. Parasit Vectors 5:79.

Invest, J.F. and Lucas, J.R. (2008): Pyriproxyfen as a Mosquito Larvicide, Proceedings of the Sixth International Conference on Urban. Budapest: Pests Europa Congress Center.

Itoh, T.; Kawada, H.; Abe, A.; Eshita, Y.; Rongsriyam, $Y$. and Igarashi, A. (1994): Utilization of blood fed females of Aedes aegypti as a vehicle for the transfer of the insect growth regulator pyriproxyfen to larval habitats. J. Am. Mosq. Control Assoc. 10: 344347.

Jacobs, D.E.; Hutchinson, M.J.; Krieger, K.J. and Bardt, D. (1996): A novel approach to flea control on cats, using pyriproxyfen. Vet. Rec. 139, 559-561.

Liénard, E.; Bouhsira, E.; Jacquiet, P.; Warin, S.; Kaltsatos, V. and Franc, M. (2013): Efficacy of dinotefuran, permethrin and pyriproxyfen combination spot-on on dogs against Phlebotomus perniciosus And Ctenocephalides canis. Parasitol Res 112: 3799-3805.

Mendes, M.C.; Lima, C.K.P.; Nogueira, A.H.C.; Yoshihara, E.; Chiebao, D.P.; Gabriel, F.H.L.; Ueno, T.E.H.; Namindome, A. and Klafke, G.M. (2011): Resistance to cypermethrin, deltamethrin and chlorpyriphos in populations of Rhipicephalus (Boophilus) microplus (Acari: Ixodidae) from small farms of the state of SãoPaulo, Brazil. Vet. Parasitol. 178, 383388.

Meyer, J.A.; Disch, D.; Cruthers, L.R.; Slone, R.L. and Endris, R.G. (2003): Repellency and efficacy of a $65 \%$ permethrin spot-on formulation for dogs against Aedes aegypti (Diptera: Culicidae) mosquitoes. Vet. Ther. 4, 135-144.

Miler, J.E. (1994): Can pyriproxyfen (an insect growth regulator) be used to prevent selection of permethrin resistance by impregnated bed nets? Trans. R. Soc. Trop. Med. Hyg. 88: 281.

Miller, R.J.; Davey, R.B. and George, J.E. (2007): First report of permethrin-resistant Boophilus microplus (Acari: Ixodidae) collected within the United States. J. Med. Entomol. 44, 308315.

Nolan, J.; Wilson, J.T.; Green, P.E. and Bird, P.E. (1989): Synthetic pyrethroid resistance in field samples in the cattle tick (Boophilus microplus). Aust. Vet. J. 66, 179-182.

Ohashi, K.; Nakada, K.; Ishiwatari, T.; Miyaguchi, J.I.; Shono, Y.; Lucas, J.R. and Mito, N. (2012): Efficacy of Pyriproxyfen-Treated Nets in Sterilizing and Shortening the Longevity of Anopheles gambiae (Diptera: Culicidae). J. Med. Entomol 2012, 49:1052-1058.

Patterson, J.W. (1974): A comparison of the morphogenetic and sterilizing activities of juvenile hormone mimics on Aedes aegypti. J. Insect Physiol. 20: 2095-2106.

Potter, M.F.; Rosenberg, B. and Henriksen, $M$. (2010): Bugs without borders: defining the global bed bug resurgence. Pest World 2010; Sept/ Oct: 8-20.

Ribeiro, V.L.; Avancini, C.; Gonçalves, K.; Toigo, E. and von Poser, G. (2008): Acaricidal activity of Calea serrata (Asteraceae) on Boophilus microplus and Rhipicephalus sanguineus," Vet. Parasitol, vol. 151, 351-354

Riddiford, L.M. and Truman, J.W. (1978): Biochemistry of Insect Hormones and Insect Growth Regulators, In: Biochemistry of Insects (Ed. M. Rockstein,). Acad. Press, New york. pp. 307-357.

Rodriguez-Vivas, R.I.; Hodgkinson, J.E.; RosadoAguilar, J.A.; Villegas-Perez, S.L. and Trees, A.J. (2012): The prevalence of pyrethroid resistance phenotype and genotype in Rhipicephalus (Boophilus) microplus in Yucatan, Mexico. Vet. Parasitol. 184, 221229.

Roe, R.M.; Donohue, K.V.; Khalil, S.M. and Sonenshine, D.E. (2008): Hormonal regulation of metamorphosis and reproduction in ticks. Front Biosci 13, 7250-7268

Sharma, A.K.; Kumar, R.; Kumar, S.; Nagar, G.; Singh, N.K.; Rawat, S.S.; Dhakad, M.L.; Rawat, A.K.S.; Ray, D.D. and Ghosh, S. (2012): Deltamethrin and cypermethrinresistance status of Rhipicephalus (Boophilus) microplus collected from sixagroclimatic regions of India. Vet. Parasitol. 188, 337-345.

Stanneck, D.; Larsen, K. and Mencke, N. (2002): An evaluation of the effect of pyriproxyfen on eggs and adults of the cat flea, Ctenocephalides felis felis (Siphonaptera: Pulicidae). Irish Vet. J. 55, 383-387 
Tiawsirisup, S.; Nithiuthai, S. and Kaewthamasorn, M. (2007): Repellent and adulticide efficacy of a combination containing $10 \%$ imidacloprid and $50 \%$ permethrin against Aedes aegypti mosquitoes on dogs. Parasitol. Res. 101, 527531.
Wijayaratne, L.K.; Fields, P.G. and Arthur, F.H. (2012): Effect of methoprene on the progeny production of Tribolium castaneum (Coleoptera: Tenebrionidae). Pest Manag Sci 68:217-224.

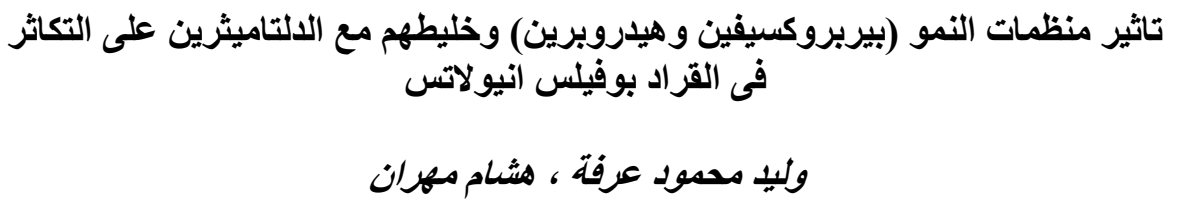

Email: wmarafa@yahoo.com

Assiut University web-site: www.aun.edu.eg

تناولت هذه الدر اسة تاثير شبيه منظمات النمو فى الحشر ات وخليطها مع الدلتاميثرين على القر اد من نوع البوفيلس انيو لاتس. تم تجميع

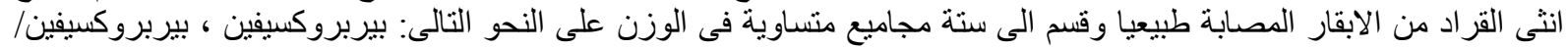

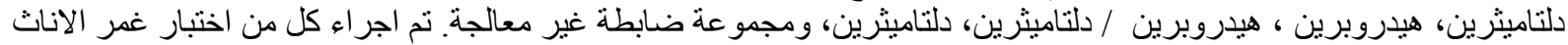

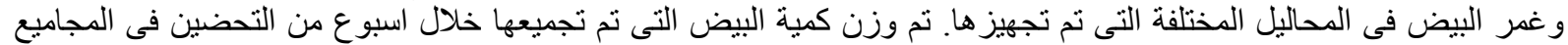

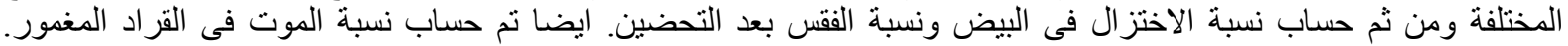

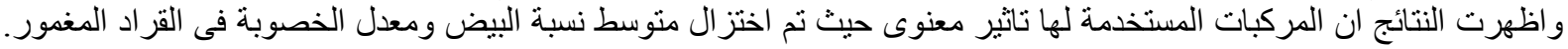

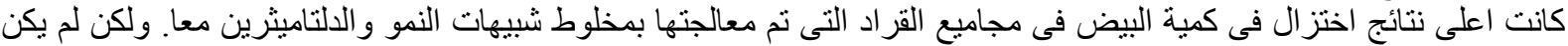

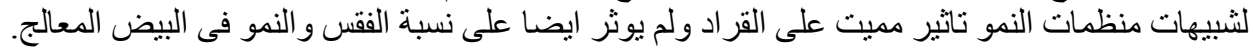

